Vol 10, Issue 10, 2017

\title{
ON THE ISSUE OF THE STUDY OF AUTOBIOGRAPHICAL MEMORY
}

\author{
SERGEY NIKOLAYEVICH NIKISHOV, IRINA STANISLAVOVNA OSIPOVA, ELENA GENNADYEVNA PRONKINA
}

Federal State Budgetary Educational Institution of Higher Education, National Research Ogarev Mordovia State University, Saransk 430005, Republic of Mordovia, Russia. Email: serg-n79@yandex.ru

Received: 13 April 2017, Revised and Accepted: 16 June 2017

\section{ABSTRACT}

Objective: The article focuses on the topical problem of the functioning of autobiographical memory, which is considered as a higher mental function. The aim of the research is to study autobiographical memory of people of different age groups using the method of free recall of events.

Methods: The main parameters of the analysis are as follows: "Memories peak," subjective importance of the events and dynamics of autobiographical memory.

Results: The research results suggest that positive experiences dominate in the structure of autobiographical memory. This may indicate psychological protective mechanisms of a person. The dynamics of autobiographical memory is observed in all age groups. This results in changing the evaluation of events. This can be explained by a change in personality, the transformation of values, interests and moral principles of a person.

Conclusion: The study revealed that subjects of all age groups primarily remember old events and, last of all, the events of the recent past.

Keywords: Autobiographical memory, Memories peak, Subjective significance, Dynamics of autobiographical memory.

(c) 2017 The Authors. Published by Innovare Academic Sciences Pvt Ltd. This is an open access article under the CC BY license (http://creativecommons. org/licenses/by/4. 0/) DOI: http://dx.doi.org/10.22159/ajpcr.2017.v10i10.19153

\section{INTRODUCTION}

Memory is one of the traditional objects of study in psychology. Its experimental study has continued for over a hundred years. During this time a certain theoretical base has been developed, a wealth of factual material has been accumulated. However, as the scientific literature analysis shows, there are still some unresolved problems related to the functioning of human memory.

At present, human autobiographical memory as a specific mnemonic subsystem is of considerable research interest.

The active study of autobiographical memory as a new independent object of study abroad began in the 1980 -ies of the $20^{\text {th }}$ century. The problem of the autobiographical memory analysis is at the confluence of general psychology, personality psychology, and developmental psychology. Today a "monoparametric" method of the study of autobiographical memory dominates in foreign psychology (D. Berntsen, D.C. Rubin, S. Bluck, M.A. Conway). This approach is devoted to searching for statistical links between the characteristics of the organization or the content of memories and some external variables.

In national psychology autobiographical memory was mainly studied in the context of the study of "a subjective view of life experience," the idea of which was created by Ananyev B.G. in the 1970-ies. Golovakha E.I., Kronik A.A., Sokhan L.V., Zlobina E.G., Karpinskiy K.V., Corzhova E.Y. made a large contribution to its development. Nurkova studied autobiographical memory in the most deeply and systematic way - she develops a concept of autobiographical memory as a higher mental function, considering it as "subjective reflection of a person's life period, implying fixing, preserving, interpreting, and actualizing the autobiographically significant events and states, which determine by the self-identity of a person" [1]. Autobiographical memory may consist of autobiographically significant events, states and self-images in different periods of life. This determines the uniqueness and selfidentity of a person. As noted by Nurkova, it can be studied at the micro (certain memories) and macro (event-driven configuration of the subjective view of the past) levels [2].

As of today, researchers have determined the place of autobiographical memory as one of the declarative memory subsystems (along with episodic and semantic memories), described its unique phenomenology, revealed a functional repertoire, and established basic laws of its functioning [3-7]. However, a question of certain characteristics of autobiographical memory, its structure, scope and limits of its variability deserves to be asked.

The analysis of this state of studies of autobiographical memory suggests the need to study and consider in a detailed way such problems as the dynamics of autobiographical memory, the influence of gender and personality characteristics on its functioning, the determination of the boundaries of the "memories peak" in people of different age. The solution of these and many other issues related to the functioning of autobiographical memory requires both traditional diagnostic procedures and new tools.

\section{METHODS}

A method of free recall of events can be one of the tools for the study of autobiographical memory.

Using this method, subjects are asked to recall and write down (by assigning a sequence number) 30 most memorable events of their lives. After the completion of the main procedures, the experiment participants should classify all events on several grounds.

First, the subjects should recall and write down how old they were when every actualized event happened. This will determine the boundaries of the "memories peak."

Second, the subjects should divide all events into positive, negative, and neutral ones. The events should be evaluated as of the present and the past. It is necessary to study the dynamics of autobiographical memory. 
Processing of results includes the calculation and comparative analysis of the events on the selected classification criteria.

\section{RESULTS}

The study, which was attended by 250 people of different age, has revealed a number of features of autobiographical memory. It has been established that for almost all age groups the "memories peak" falls on the actual age or the preceding age. In particular, $80.4 \%$ of autobiographical memories of elementary schools relate to the elementary school age, $42.8 \%$ of the information reproduced by teenagers relates to the adolescence. The analysis of adolescents' memories showed that $33.1 \%$ of memories actualized in the course of the study relate to the late adolescence. $33.3 \%$ of events reproduced by middle-aged participants happened in the middle adulthood. The results obtained in the eldest age group are different. According to the studies conducted by Nikishov and Osipova, the "memories peak" in the elderly occurred in the middle adulthood (32.8\%), not in the elderly age [8].

The analysis of autobiographical memories on subjective importance (evaluation in terms of the present) showed that subjects recalled positive events more often $(77.2 \%)$ than the negative ones $(21.5 \%)$, while the proportion of neutral events is $1.3 \%$. The greatest number of positive events was recalled by teenagers $(85.4 \%)$ and the elderly $(80.7 \%)$. In descending order, the following are elementary schools (75.8\%) and the elderly (74.3\%). The elderly participants are at the end of the list (70.0\%). These results suggest that the proportion of negative events in the structure of autobiographical experience does not exceed $30.0 \%$. The largest number of negative memories was observed among young men $(26.6 \%)$, the elderly $(24.3 \%)$, and elementary schools (23.1\%); the fewest number of negative memories were observed among teenagers $(14.6 \%)$ and middle-aged people $(18.7 \%)$.

The data obtained during the study allowed to reveal the dynamics of autobiographical memory. This is one of the most important and poorly studied features. It has been found that differences in the evaluation of events by the subjects (in terms of the present and the past) comprise $12.0 \%$. The research results suggest that the dynamics of autobiographical memory of elementary schools is $10.1 \%$. The events happened in the early preschool age $(21.0 \%)$ underwent the greatest changes in the evaluation. Teenagers' dynamics of autobiographical memory is $11.6 \%$. As in the previous age group, the events of the early preschool age (36.1\%) have been greatly revaluated. The dynamics of autobiographical memory among adolescents is $16.5 \%$. Most of all they changed their attitude to the events that have taken place in the early and middle preschool age (26.2\%). Almost similar situation can be observed among middle-aged and elderly people. The dynamics of autobiographical memory is $10.8 \%$ and $10.9 \%$, respectively. Changes mostly relate to the events of primary school age: Middle-aged people assessed $17.8 \%$ of their memories in a different way, while the elderly changed their attitude to $20.2 \%$ of the events reproduced.

The analysis of autobiographical memories reveals an important feature that is common to all age groups. First of all, the participants recalled the events happened in the relatively distant past (Table 1).

Table 1: Average age of the subjects at the time of the event occurrence

\begin{tabular}{lll}
\hline Subjects of the study & \multicolumn{2}{l}{$\begin{array}{l}\text { The subjects' age at the time of } \\
\text { the event occurrence }\end{array}$} \\
\cline { 2 - 3 } & Event \#1 & Event \#30 \\
\hline Elementary schools & 7.3 & 8.2 \\
Teenagers & 8.8 & 10.5 \\
Adolescents & 10.1 & 17.6 \\
Middle-aged people & 10.4 & 38.1 \\
Elderly & 18.0 & 50.4 \\
\hline
\end{tabular}

Thus, the average age of subjects of the study at the time of the event occurrence, recorded in reports under number one, is as follows: Primary school children - 7.3 years old, teenagers - 8.8 years old, adolescents -10.1 years old, middle-aged people -10.4 , and the elderly -18.0 years old.

It has been revealed that the events actualized by the subjects relate to the relatively recent past last of all (Table 1). The average age of participants in the experiment at the time of occurrence of the reproduced event under number 30, is as follows: Primary school children - 8.2 years old, teenagers - 10.5 years old, adolescents 17.6 years old, middle-aged people - 38.1 years old, and the elderly 50.4 years old.

\section{DISCUSSION}

The study revealed that, in contrast to the other age groups, the "memories peak" of the elderly falls not on the actual age, but on the preceding age, i.e., on the period of the middle adulthood. This feature is largely determined by the action of the mechanism of personal psychological protection. Its implementation is carried out by immersion into the past, by recalling the past events. Autobiographical memory is a personal resource helping the elderly compensate for the lack of positive emotions in the present, adapt to new conditions of life, the social status changed and the health deterioration. In other words, autobiographical memory becomes a tool to solve (at least partially) the problem of the personal adaptation of the elderly to the decline of life.

The following issue has been repeatedly discussed in the scientific literature: What is remembered and, consequently, better reproduced - positive or negative events. Discussion of this issue began in the early $20^{\text {th }}$ century and continues up to date $[9,10]$.

According to some researchers, mostly pleasant memories are remembered (Freud). In his opinion, "the tendency to forgetting bad events is universal, although this ability is unequally developed in people" [11]. Freud believed that the "I" blocks internal impulses and threats of the "Super I." "In this case, unpleasant and similar experience is repressed out of the sphere of consciousness" [11]. Thus, he explains this feature as the work of psychological protective mechanisms of a person. According to the other scholars, unpleasant events are better remembered [12].

Rubinstein presented another approach to solving this problem. He analyzed the experience gained and came to the conclusion that in such statement this problem does not imply a unique solution. "Under otherwise equal conditions emotionally rich events will be better remembered than emotionally neutral ones; but in some cases, pleasant and unpleasant events will be better remembered and reproduced, depending on what is more relevant in this particular case..." - noted Rubinstein [13].

The experimental study has confirmed Rubinstein's position in as much as he thinks that a person better remembers emotionally meaningful and emotionally rich events. Our study confirmed the fact that neutral events are remembered much worse. As already noted, the subjects remembered only a small number of events that had been classified as neutral.

However, it may become necessary to ask the following question: "Why have neutral events been remembered and subsequently reproduced if they are not emotionally meaningful for a person?" "This can be explained by the fact that in addition to the emotional experience, the general emotional state of a person can sometimes play a significant role at the time when a neutral event was perceived."

Concerning the issue what is better remembered - positive or negative events, our findings are consistent with the views of Freud. Since the subjects reproduced mostly positive autobiographical events rather 
than negative ones, we can conclude that positive events are more relevant and more significant, which are firmly fixed in memory.

The prevalence of positive events in the structure of autobiographical experience helps personality remain stable and function properly, since; according to Ross B. "autobiographical recollection is. a process generated by the subject's need to be confident of the stability of the "I" and the need to know the facts acceptable for such confidence" [14].

The study allowed us to record the fact of the dynamics of autobiographical memory. All participants changed the opinion of past events. We assume that this is closely linked to the personality change, the transformation of values, interests and moral principles of a person. At the same time, the events of the distant past are mostly reinterpreted.

Another feature found in the study is as follows: The vast majority of subjects using our proposed method remember events from earlier periods of their life, and then they recall the events of the recent past. This can be explained by the fact that they arbitrarily or inadvertently set a specific algorithm for the process of reproduction of autobiographical memories.

\section{CONCLUSION}

In conclusion, it should be noted again that the solution of many issues of the functioning of autobiographical memory requires both traditional diagnostic procedures and new tools with an account of age, gender, and personal characteristics of the subjects.

\section{ACKNOWLEDGMENTS}

The study was funded by Russian Foundation for Humanities upon grant No. 16-36-01038 "Autobiographical memory: Age peculiarities, gender differences, and personal characteristics."

\section{REFERENCES}

1. Nurkova VV. Avtobiograficheskaya pamyat kak problema psikhologicheskogo issledovaniya [Autobiographical memory as a problem of psychological research]. Psychol J 1996;2:16-29.

2. Nurkova VV. Svershennoe Prodolzhaetsya: Psikhologiya Avtobiograficheskoi Pamyati Lichnosti [Accomplishment Continues: Psychology of Autobiographical Memory Card of a Person]. Moscow: Publishing house URAO; 2000.

3. Neisser U, Hyman A. Kognitivnaya Psikhologiya Pamyati [Cognitive Psychology of Memory]. Moscow: Olma-Press; 2005.

4. Nurkova VV. Kul Turno-Istoricheskii Podkhodk Avtobiograficheskoi Pamyati [The Cultural-Historical Approach to Autobiographical Memory]. Abstract of the PhD Thesis. Moscow: Moscow State University Named after M. V. Lomonosov; 2009.

5. Conway MA. Commentary: Cognitive-affective mechanisms and processes in autobiographical memory. Memory 2003;11(2):217-24.

6. Robinson JA. Sampling autobiographical memory. Cogn Psychol 1976;8(4):578-95

7. Tulving E. Origin of autonoesis in episodic memory. The Nature of Remembering: Essays in Honor of Robert G. Crowder. Vol. 3. Washington, DC: American Psychological Association; 2001. p. 172-81.

8. Nikishov SN, Osipova IS. K voprosu o funktsionirovanii avtobiograficheskoi pamyati lyudei pozhilogo vozrasta [On the issue of the functioning of autobiographical memory in the elderly]. Russian Sci J 2014;3(41):119-24.

9. Shelat DY, Acharya SR. Neuroprotective Activity of novel cur-ca-thione and its oxidative stress study. Int J Pharm Pharm Sci 2016;8(12):167-73.

10. Krishnan VG, Murugan K. Solanum protease inhibitors and their therapeutic potentialities. Int J Pharm Pharm Sci 2016;8(12):14-21.

11. Freud S. Psikhoanaliz Detskikh Nevrozov [Psychoanalysis of Childrens Neuroses]. Moscow: State Publishing; 1925.

12. Blonsky PP. Izbrannye Pedagogicheskiei Psikhologicheskie Sochineniya v Dvukh Tomakh [Selected Pedagogical and Psychological Essays in Two Volumes]. Moscow: Pedagogy; 1979.

13. Rubinstein SL. Osnovy obshchei Psikhologii [Fundamentals of General Psychology]. St. Petersburg: Piter; 2001

14. Ross BM. Remembering the Personal Past: Descriptions of Autobiographical Memory. Oxford, New York: University Press; 1991. 